\title{
IMMUNE RESPONSE OF SHEEP AT SUBCHRONIC INTOXICATION BY PYRETHROID INSECTICIDE SUPERCYPERMETHRINE
}

\author{
I. MIKULA, J. PISTL and P. KAČMÁR \\ Department of Microbiology and Immunology, University of Veterinary Medicine, \\ Komenského 73, 04181 Košice
}

Received April 3, 1991

\begin{abstract}
Mikula I., J. Pist1, P. Kačmár: Immune Response of Sheep at Subchronic Intoxication by Pyrethroid Insecticide Supercypermethrine. Acta vet. Brno, 61, 1992: $57-60$.

Testing of the influence of subchronic ( 6 weeks) load of sheep organism caused by the pyrethroid insecticide supercypermethrine on functionality of cells of the immune system was carried out. Insecticide was administered daily in molasses feed in the doses 50,200 and $300 \mathrm{mg} . \mathrm{kg}^{-1}$ of live weight. During the last two weeks (5th to 6 th weeks) of the experiment we recorded a decrease of the phagocytic index dependent on the supercypermethrine dose. Percentage of E rosette forming cells and the migration index were either unchanged or displayed insignificant dose-dependent values.
\end{abstract}

Pyrethroid insecticide, supercypermethrine, sheep, phagocytic activity, $E$ rosette test, leucocyte migration index

Outer environment represents the source of a great number of different chemical factors influencing the immune response of humans and animals (Moore and Faith 1976). Many chemical preparations have been developed and applied in free nature during the recent decades. This refers most often to herbicides and insecticides. Their wide-area application brings along the toxicological hazards as well. Characteristics of pesticides from the viewpoint of their influence on animal health represents a highly topical aspect of the present. Besides the classical toxicological methods for testing of insecticide harmlessness, an important role is played by the immunological examinations which allow to detect even very moderate toxicological risk (Vos et al. 1982; Desi et al. 1986). Presented study followed the influence of the pyrethroid insecticide supercypermethrine on cellular immune response of sheep. Synthetic pyrethroids represent a new group of insecticides. Cypermethrine (type II pyrethroid), m. w. 413.3, contains cyanide group $\left(\mathrm{CN}^{-}\right)$and its empiric formula is: $\mathrm{C}_{2}, \mathrm{H}_{19} \mathrm{Cl} \mathrm{NO}_{3}$ (Sapiets et al. 1984). It belongs among oral and contact insecticides with wide effect on a whole range of noxious insects (e. g. Lepidoptera, Coleoptera, Hemiptera, etc.). It is very effective in small amounts, for example, preparation Ripkord in the dose of $0.1-0.21 . \mathrm{ha}^{-1}$ (Sedokur 1986), 25-75 g. ha-1 (Piskač et al. 1985). Resistance of insects to this preparation is small and its action affects various developmental stages (eggs, larvae, adult insects). It is easily applied (sprays, emulsions, powders). Acute oral $\mathrm{LD}_{50}$ in rats is most trequently specified within the range $200-300 \mathrm{mg} \cdot \mathrm{kg}^{-1}$ (Sapiets et al. 1984; Sedokur 1986; Melnikov et al. 1980), in mice $63-805 \mathrm{mg} \mathrm{.} \mathrm{kg}^{-1}$, in chicken $200 \mathrm{mg} . \mathrm{kg}^{-1}$ (Sapiets et al. 1984; Marhold et al. 1986). It is used not only against noxious insect species (flies, horseflies, cockroaches, mosquitos) but also as an ectoparasitic preparation (e.g. scab).

\section{Materials and Methods}

\section{Experimental animals}

Sheep of Slovak merino breed of both sexes, aged 7 months, $21-28 \mathrm{~kg}$ of live weight, were used as model animals in the study of subchronic ( 6 weeks) intoxication. They were divided into three groups, five animals in each. Insecticide substance supercypermethrine added to the molasses feed was administered to sheep of the first experimental group in the daily dose $50 \mathrm{mg} \cdot \mathrm{kg}^{-1}$ of live 
weight. Sheep of the second experimental group were offered the tested insecticide in the daily dose $200 \mathrm{mg} \cdot \mathrm{kg}^{-1}$ of live weight, which was increased to $300 \mathrm{mg} \cdot \mathrm{kg}^{-1}$ of live weight after four weeks of experiment. The third group of sheep served as a control.

\section{Blood sampling}

Blood samples were obtained in one-week intervals during 7 weeks, in morning hours.

\section{Immunological testing}

a) Determination of phagocytic activity (PA)

Phagocytic activity and the phagocytic index of peripheral blood polymorphonuclears were determined using microspherical hydrophilic particles (MSHP kit, Institute for Research, Production and Utilization of Radioisotopes, Prague, according to Větvička et al. 1982).

b) Phagocytic index (PI)

Mean number of engulfed particles per one potentially phagocytic cell was determined as follows: $P I=$ number of engulfed particles/100 potential phagocytes

c) Determination of $\mathrm{E}$ rosettte forming lymphocytes ( $\mathrm{E}$ rosette test, ER).

Lymphocytes were isolated by means of Lymphoprep (Nyegaard, Oslo) using Harris and Ukaejiofo method (1969). E rosette test was carried out according to Binns (1978) method. Percentage of rosette forming lymphocytes was calculated as follows:

$\%$ of rosettes $=$ number of rosettes $\times 100 / 200$ lymphocytes

A lymphocyte with 3 or more attached lymphocytes was considered as rosette.

d) determination of inhibition of leucocyte migration (capillary migration-inhibition test MIT) (Bendixen et al. 1976).

Leucocytes were isolated from calf blood using the method of osmotic lysis of erythrocytes in deionized water (Karlson and Kaneko 1973). Each leucocyte sample was tested 3-times with mitogene (Phytohemagglutinin, HA-15, Wellcome, England) and without mitogene. Test was evaluated after 24 -hrs incubation at $37^{\circ} \mathrm{C}$. Migration index (MI) was calculated on the basis of ratios of areas of leucocyte migration with mitogene $(\mathrm{Mx})$ and areas without mitogene $(\mathrm{Mo}): \mathrm{MI}=$ $=M \times / M o$. Evaluation of MIT was carried out according to Wilson et al. (1982).

Evaluation of tests

Mean values $(x+s d)$ of immunological tests in animal groups were evaluated by the Student's t-test to determine the significance at $95 \%$ level.

Table 1

Values of immunological tests at application of supercypermethrine in experimental sheep

\begin{tabular}{|c|c|c|c|c|c|c|c|c|}
\hline \multirow{2}{*}{$\begin{array}{l}\text { Group of } \\
\text { sheep } \\
n=5\end{array}$} & \multirow[b]{2}{*}{. Tests } & \multicolumn{7}{|c|}{ Week of blood sampling } \\
\hline & & $\begin{array}{c}0 \\
\mathbf{x} \pm \text { sd }\end{array}$ & $\stackrel{\text { I. }}{\mathrm{x} \pm \mathrm{sd}}$ & $\begin{array}{l}\text { II. } \\
\mathrm{x} \pm \mathrm{sd}\end{array}$ & $\begin{array}{l}\text { III. } \\
\mathrm{x} \pm \mathrm{sd}\end{array}$ & $\begin{array}{c}\text { IV. } \\
\mathbf{x} \pm \text { sd }\end{array}$ & $\begin{array}{c}\text { V. } \\
\mathbf{x} \pm \text { sd }\end{array}$ & $\begin{array}{l}\text { VI. } \\
x \pm \text { sd }\end{array}$ \\
\hline I. & $\begin{array}{l}\text { PA } \\
\text { PI } \\
\text { ER } \\
\text { MI }\end{array}$ & $\begin{array}{c}83.6 \pm 0.8 \\
12.7 \pm 1.1 \\
35.4 \pm 2.3 \\
0.6 \pm 0.11\end{array}$ & $\begin{array}{l}81.4 \pm 1.2 \\
10.2 \pm 0.8 \\
34.2 \pm 2.5 \\
0.68 \pm 0.09\end{array}$ & $\begin{array}{c}79.4+1.1 \\
9.6 \pm 0.8 \\
34.6 \pm 1.9 \\
0.77 \pm 0.11\end{array}$ & $\begin{array}{c}79.6 \pm 1.4 \\
8.7 \pm 0.5 \\
36.4 \pm 2.2 \\
0.63 \pm 0.08\end{array}$ & $\begin{aligned} 80.2 & \pm 0.7 \\
8.4 & \pm 0.9 \\
32.8 & \pm 2.6 \\
0.74 & \pm 0.13\end{aligned}$ & $\begin{array}{c}78.6 \pm 1.2 \\
8.3 \pm 0.9 \\
30.0 \pm 1.4 \\
0.77 \pm 0.09\end{array}$ & $\begin{array}{r}77.4 \pm 1.6 \\
8.4 \pm 0.9 \\
28.6 \pm 2.7 \\
0.80 \pm 0.1\end{array}$ \\
\hline II. & $\begin{array}{l}\text { PA } \\
\text { PI } \\
\text { ER } \\
\text { MI }\end{array}$ & $\begin{array}{l}81.2 \pm 1.0 \\
13.1 \pm 1.1 \\
35.8 \pm 2.1 \\
0.74 \pm 0.06\end{array}$ & $\begin{array}{l}78.8 \pm 2.5 \\
10.7 \pm 1.0 \\
35.0 \pm 1.8 \\
0.79 \pm 0.12\end{array}$ & $\begin{array}{c}81.6 \pm 1.5 \\
8.6 \pm 0.6 \\
36.2 \pm 3.2 \\
0.88 \pm 0.07\end{array}$ & $\begin{aligned} 79.1 & \pm 1.4 \\
8.3 & \pm 0.6 \\
36.4 & \pm 2.0 \\
0.76 & \pm 0.06\end{aligned}$ & $\begin{array}{r}78.2 \pm 2.7 \\
7.4 \pm 0.7 \\
31.0 \pm 1.9 \\
0.81 \pm 0.1\end{array}$ & $\begin{array}{c}78.4 \pm 1.7 \\
5.2 \pm 0.5 * \\
29.2 \pm 3.2 \\
0.88 \pm 0.1\end{array}$ & $\begin{array}{c}76.6 \pm 2.2 \\
5.4 \pm 0.5 * \\
23.6 \pm 1.6 \\
0.87 \pm 0.08\end{array}$ \\
\hline $\begin{array}{l}\text { III. } \\
\text { (C) }\end{array}$ & $\begin{array}{l}\text { PA } \\
\text { PI } \\
\text { ER } \\
\text { MI }\end{array}$ & $\begin{array}{l}83.4 \pm 2.3 \\
14.2 \pm 0.5 \\
35.0 \pm 2.7 \\
0.59 \pm 0.16\end{array}$ & $\begin{array}{l}83.4 \pm 1.2 \\
12.3 \pm 0.9 \\
36.2 \pm 2.2 \\
0.78 \pm 0.1\end{array}$ & $\begin{array}{l}77.8 \pm 2.7 \\
10.4 \pm 0.8 \\
34.2 \pm 2.8 \\
0.61 \pm 0.08\end{array}$ & $\begin{array}{c}80.4 \pm 1.1 \\
8.5 \pm 0.8 \\
35.8 \pm 1.8 \\
0.57 \pm 0.08\end{array}$ & $\begin{array}{r}81.0 \pm 1.5 \\
8.5 \pm 0.6 \\
33.0 \pm 2.4 \\
0.62 \pm 0.1\end{array}$ & $\begin{array}{c}76.8 \pm 1.6 \\
8.2 \pm 0.5 \\
34.4 \pm 2.5 \\
0.70 \pm 0.07\end{array}$ & $\begin{array}{c}75.0 \pm 2.5 \\
8.7 \pm 0.6 \\
32.3 \pm 3.1 \\
0.72 \pm 0.67\end{array}$ \\
\hline
\end{tabular}

Legend: $*=$ statistically significant result as determined by the Student's t-test $(p<0.05)$

PA = phagocytic activity (\%)

PI = phagocytic index

$E R=\mathbf{E}$ rosettes (\%)

$\mathrm{MI}=$ migration index 


\section{Results}

Immunological determinations were conducted in weekly intervals and the summary of results is presented in Table 1 . Phagocytic activity did not display more pronounced differences of values in any group of sheep. In the 5th week of the experiment sheep of the second group, which received the highest dose of preparation, showed a marked decrease of the phagocytic index $(5.2 \pm 0.5)$ compared to the first $(8.3 \pm 0.9)$ and the control groups $(8.2 \pm 0.5)$. Statistically significant difference of PI values was recorded in the second group during the 5 th and 6th week of the experiment $(p<0.05)$.

In the 6th week, we observed a marked decrease of number of $E$ rosette forming lymphocytes $(23.6 \pm 1.6 \%)$, in the second group of sheep compared to the control group $(32.2 \pm 3.1 \%)$, however, this difference was not statistically significant. Mean values of the leucocyte migration index obtained in sheep of the second experimental group were on the positivity margin expressed by capability of lymphocytes to react to the mitogenic impulse of phytohemagglutinine. Mentioned differences of migration index values were not statistically significant.

\section{Discussion}

Mechanism of action of photostabile synthetic pyrethroids differs from that of organophosphates mainly by the fact that they do not integrate with the acetylcholine-esterase system (E1liot et al. 1978). Their oral, dermal and inhalation toxicity is low since the metabolizing enzymes prevent their penetration into the nervous system (E1liot et al. 1978).

Desi et al. $(1980,1984,1985,1986)$ studied the effect of pesticide cypermethrine on the immune system of rats and rabbits. They discovered a dose-dependent significant $(p>0.05, p<0.01)$ decrease of specific antibody titre (anti-ovoalbumine blood serum titre) at subacute intoxications of rats $(1 / 40,1, / 20,1 / 10$ $\left.\mathrm{LD}_{50}\right)$. This decrease was accompanied by decreased hypersensitivity reaction of the delayed type and peripheral blood lymphocyte decline (tested by the E rosette test) after 6 to 12 weeks of cypermethrine application.

We recorded in sheep a supercypermethrine dose-dependent statistically insignificant decrease of PI during the last two weeks (5th and 6th weeks) of our experiment. Other parameters (ER, MI) remained either unchanged or showed dose-dependent, although statistically insignificant differences. These results make it possible to state, that longer lasting intake of supercypermethrine in relatively high doses can results in the damage of the immune state of experimental sheep.

\section{Imunologické vyšetrenie oviec $\mathrm{v}$ podmienkach subchronickej intoxikácie pyretroidovým insekticídom supercypermetrinom}

Bol testovaný vplyv subchronického 6týždňového zataženia organizmu oviec pyretroidným insekticídom supercypermetrinom na funkčnost' buniek imunitného systému. Insekticíd bol podávaný denne $\mathrm{v}$ melasovom krmive $\mathrm{v}$ dávkach 50,200 , resp. $300 \mathrm{mg} \cdot \mathrm{kg}^{-1}$ živej hmotnosti. V posledných dvoch týždňoch (5. až 6. týždeň) pokusu bol zaznamenaný na dávke supercypermetrinu závislý pokles indexu fagocytárnej aktivity. Percento E rozet tvoriacich buniek a migračný index boli bữ nezmenené alebo vykazovali na dávke závisle nesignifikantné hodnoty. 


\section{Іммүнипогическое исспедование овец в үсповиях сүбхронической интоксикации пиретроидным инсектицидом сүперциперметрином}

Проверяли влияние субхронической (шестинедельной) нагрузки организма овец пиретроидным инсектицидом суперциперметрином на функциональность клеток иммунитной системы. Инсектицид подавали ежедневно с кормовой патокой дозой 50, 200, а также $300 \mathrm{mr.kr}^{-1}$ живой массы. В течение последних двух недель (на 5-6 неделе) эксперимента наблюдали от дозы суперциперметрина зависимое понижение индекса фагоцитарной активности. Процент Е розеток образующих клеток и индекс миграции оставались без изменений или отличались зависимой от дозы несүщественной величиной.

\section{References}

BENDIXEN, G.-BENTZEN, K-CLAUSEN, J. E.-KJAER, M.-SOBORG, M.: Inhibition of human leucocyte migration. In: Lymphocytes. Isolation, fractionation and characterization. Edit. J. B. Natvig P. Perlmann and H. Wigzell. Scand. J. Imm unol., suppl. 5, 1976: 264-267 BINS, R. M.: Lymphocyte membrane markers. J. Immunol. Methods, 21, 1978: 198-210

DÉSI, I.-VARGA, L.-FARKAS, I.: The effect of DDVP, on organophosphorus pesticide on the humoral and cell-mediated immunity of rabbits. Arch. Toxicol. Suppl., 4, 1980: 171-174

DÉSI, I.-VARGA, L.-DOBRONYI, I.-SZKLENARIK, G.: Immunotoxicological effect of some pesticides. Abstract of International seminar on the Immunological System, Luxemburg, 1984: 75-76

DÉSI, I. - VARGA, L.-DOBRONYI, I.-SZKLENARIK, G.: Immunological Investigation of the Effects of a Pesticide Cypermethrin. Arch. Toxicol., Suppl. 8, 1985: 305-309

DÉSI, I.-D○BRONYI, I.-VARGA, L.: Immuno, Neuro, and General Toxicologic Animal Studies on a Synthetic Pyrethroid: Cypermethrin. Ecotoxicology and environmental safety, 12, 1986: 220-232

ELLIOT, M.-JANES, N. F.-POTTER, C.: The future of pyrethroids in insect control. Annu. Rev. Entomol., 23, 1978: 443-468

HARRIS, R.-UKAEJIOFO, E. V.: Rapid preparation of lymphocytes for tissue typing. Lancet, 327, 1969: 7615

KARLSON, KANEKO: Isolation of leukocytes from bovine peripheral blood. Proc. Soc. expl. Biol. Med., 142, 1973;: 853-856

MARHOLD, J.: Přehled průmyslové toxikologie. Organické látky, svazek 2, Avicenum, Praha, 1986: 913

MĚLNIKOV, N. N.-NOVOŽILOV, K. V.-PYLOVA, T. N.: Chimičeskije sredstva zaščity rastenij. Spravočnik, 1980: 217

MOORE, A. J.-FAITH, R. E.: Immunologic response and factors affecting its assessment. Target Organ Toxicity Symposium on Development. Chapel Hill North Carolina, 1976

PISKAČ, A.-KAČMÁR, P.: Veterinární toxikologie, SZM, Praha, 1985: 102-103

SAPIETS, A. - SWAINE, H.-TANDY, M. J.: Cypermethrin. Analytical methods for pesticides and plant growth regulators. Vol. XIII, 1984: 33-51

SEDOKUR, L. K.: Spravočnik po pesticidam. No. 267 Ripkord, Kijev, ,Urožaj“‘, 1986: 289-290

VĚTVICKKA, V.-FORNUSEK, L.-KOPECEK, J.: Phagocytosis of human blood leucocytes: a simple micromethod. Immunology Letters, 5, 1982: 97-100

VOS, J. G.-KRAJNIC, E. I.-BEEKHOF, P. K.-VanLOGTEN, M. J.: Estimation of the immunotoxicity of different pesticides in rats. 5th Int. Cong. on Pesticide Chemistry, Kyoto, Japan, 1982

WILSON, G. V.-METCALF, J. F.-FUDENBERG, H. H.: Treatment of Mycobacterium fortuitum Pulmonary Infection with "Transfer Factor"; New Methodclogy for Evaluation TF Potency and Predicting Clinical Response. Clin. Immunol. and Immunopathol., 23, 1982: 478-491 